Research Article

\title{
Integration of Sorghum [Sorghum bicolor (L.) Conard Moench.], Sunflower (Helianthus annuus L.) and Parthenium (Parthenium hysterophorus L.) Allelopathy for Weed Management in Maize under different Tillage Regimes.
}

\author{
Haroon Ur Rashid ${ }^{1 *}$, Nazia Tahir ${ }^{2}$, Muhammad Zamin $^{3}$, Naveed Shehzad ${ }^{4}$, Aman Ullah', Bibi Zainub ${ }^{5}$ \\ and Farooq Azam ${ }^{6}$
}

${ }^{1}$ Department of Agronomy, The University of Haripur, Khyber Pakbtunkbwa, Pakistan; ${ }^{2}$ Department of Agriculture, Abdul Wali Khan University Mardan (AWKUM), Pakistan; ${ }^{3}$ Department of Agriculture, University of Swabi, Pakistan; ${ }^{4}$ Department of Horticulture, The University of Haripur, Pakistan; ${ }^{5}$ Department of Horticulture, The University of Agriculture Peshawar, Pakistan; ${ }^{6}$ Department of Plant and Environmental Protection, PARC Institute of Advanced Studies in Agriculture Islamabad, Pakistan.

Abstract | Weed infestation is considered a significant yield reducing factor in maize yield around the world as well as in the south Asia. Integrated weed management (IWM) is recommended to reduce our reliance on synthetic herbicides and sustainable maize production. In this study, different tillage regimes and various allelopathic treatments were integrated for weed management in spring planted maize at Agricultural Research Station, Swabi (KP), Pakistan during spring both years 2014 and 2015. The experiment was laid out at silt loam soil in Randomized Complete Block Design (RCBD) with a split plot arrangement having three (03) replications. Different tillage regimes namely minimum, conventional, and deep tillage regimes were assigned to main plots (Factor A) and various allelopathic plants [Sorghum \{Sorghum bicolor (L.) Conard Moench.\}, Sunflower (Helianthus annuus L.) and Parthenium (Parthenium hysterophorus L.)] residues as surface mulches and their water extracts integrated @ 15L each +atrazine @ $0.125 \mathrm{~kg} \mathrm{a.i} \mathrm{ha}{ }^{-1}\left(1 / 4^{\text {th }}\right.$ of the recommended dose) was assigned to sub plots (Factor B). Data were recorded and analyzed for dry biomass ( $\mathrm{g}$ ) of total weeds 60 DAS, leaf area $\left(\mathrm{cm}^{2}\right)$, leaf area Index $(\%)$ and Stover yield $\left(\mathrm{Kg}_{\mathrm{ha}} \mathrm{h}^{-1}\right)$. Integration of tillage regimes and various allelopathic treatments had significant effect on tested parameters. However, the efficacy of surface mulches was more pronounced than atrazine foliar application @ $0.50 \mathrm{~kg} \mathrm{a} . \mathrm{i} \mathrm{ha}{ }^{-1}$ and allelopathic plants water extracts combined with atrazine @ $0.125 \mathrm{~kg}$ a.i ha ${ }^{-1}$. Data obtained for the interaction effect (tillage $\mathrm{x}$ weed control treatments) showed that maximum stover yield of $12426 \mathrm{~kg} \cdot \mathrm{ha}^{-1}$ was recorded in sorghum +sunflower + parthenium (S.M) each @ $6 \mathrm{Mg} \mathrm{ha}^{-1}$ at 3-4 leaf stage of maize under conventional tillage regime. Hence it could be considered as an alternative to atrazine @ $0.50 \mathrm{~kg}$ a.i ha ${ }^{-1}$ (recommended dose) for weed management in spring planted maize. However, further studies are suggested to investigate the phytotoxic effect of these plants' residues on soil microbial activities.

Received | June 26, 2021; Accepted | July 08, 2021; Published | September 14, 2021

*Correspondence | Haroon Ur Rashid, Department of Agronomy, The University of Haripur, Khyber Pakhtunkhwa, Pakistan; Email: haroonkhanaup@yahoo.com

Citation | Rashid H.U., N. Tahir, M. Zamin, N. Shehzad, A. Ullah, B. Zainub and F. Azam. 2021. Integration of sorghum [Sorghum bicolor (L.) Conard Moench.], Sunflower (Helianthus annuus L.) and Parthenium (Parthenium hysterophorus L.) allelopathy for weed management in maize under different tillage regimes.. Sarhad Journal of Agriculture, 37(4): 1323-1333.

DOI | https://dx.doi.org/10.17582/journal.sja/2021/37.4.1323.1333

Keywords | Allelopathy, Maize, Integrated weed management, Surface mulches, Tillage, Water extracts

December 2021 | Volume 37 | Issue 4 | Page 1323 


\section{Introduction}

$\mathrm{M}$ aize (Zea mays L.) is an important spring and autumn cereal crop and ranked $3^{\text {rd }}$ after wheat and rice in Pakistan. Due to its higher per unit area productivity and wider range of adaptability it is also known as "Queen of Cereals" (Kumar et al., 2017). It contributes $2.6 \%$ to value addition in agriculture and $0.5 \%$ to GDP (GoP, 2020). In Pakistan, $60 \%$ of aggregate maize production is used in the poultry feed sector, $25 \%$ in wet milling and other businesses, with the remainder utilized as nourishment for human and animals (Reddy and Jabeen 2016). In Pakistan, maize is cultivated on an area of 1413 thousands hectares and has average annual production of 7.24 million tons (GoP, 2020). Current average yield of maize in Pakistan is 12 tons ha ${ }^{-1}$ which is very low as compared to other developed countries of the world. Various factors are responsible for low average yield of maize in Pakistan, however weeds are consider the most important and yield reducing factor in crops and especially maize crop. Yield reduction in maize due to weeds are ranged from 24-83\% (Fahad et al., 2014). .The predominance and competitive ability of weeds with maize or corn varies due to the geographical location, competitive ability of the variety planted, nutrients availability, availability of moisture, soil type and soil management.

In Pakistan, on commercial level weeds are still managed through synthetic herbicides because of its economic value, effectiveness and fast action and availability. Weed management appeared an easy job, after the introduction of 2-4D in 1944 (era of $2^{\text {nd }}$ world war) followed by its correspondent products having different mode of actions and specificity, however the utilization of herbicides was kept under observations when resistance development of diclofop was reported in early 1980 at the Oregon state USA. Incongruously, with the passage of time the number of resistance weeds were increased to different herbicides. Very recent inclusive survey of Heap (2020) described a miserable picture of resistance weeds across the globe. He reported 512 exclusive cases (species $\mathrm{x}$ site of action) of herbicide resistance weeds worldwide, with 262 species (152 dicots and 110 monocots) have been reported in 93 crops in 70 countries. Apart from herbicide resistance in weeds, non judicious application of synthetic herbicides is considered a potential threat to environment and health related concerns in humans and animals globally (Khan et al, 2010; Jabran,
2018). Ecologist are having extremely concerned regarding the undiscerning use of synthetic herbicides. Recently 38 weed species have now evolved resistance to glyphosate, in glyphosate resistance crops, spread across 37 countries of the world infesting 34 different crops and six non crop situations (Heap and Duke, 2018) which include some worst weeds of the world. Therefore, primary reliance on synthetic herbicides has become vague and alternate weed management techniques are crucial. Non judicious usage of herbicide is lashing agro ecosystems towards decreasing species diversity and in many situations and leading to herbicide resistance (Powels and $\mathrm{Yu}, 2001 ; \mathrm{Vi}^{-}$ la-Aiub et al., 2005). Hand weeding is labor intensive, time consuming and getting more expensive, hence mostly impracticable. Cultural control is environment friendly, but result is very slow. The trend of managing weeds through allelochemicals are emerging as a potential alternative to synthetic herbicide. Several crops and weeds species are known to be allelopathic and their chemistry could be used as a tool for sustainable weed management. Parthenium hysterophorus (L.) (Hassan, 2018, Rashid et al., 2008, Safdar, 2014), Sorghum bicolor (L.) (Weston and Duke, 2003) and sunflower (Spring et al., 1992; Macias et al., 2002). In most recent research, it is reported that Sorghum bicolor, Parthenium and sunflower have strong allelopathic effects and their water extracts could be further considered for sustainable weed management in maize (Rashid et al., 2020; Rashid et al., 2022). Moreover, it is also observed that water extract of sorghum, sunflower and parthenium applied in combination were more effective than their sole applications, however, were less effective than atrazine (Rashid et al., 2020; Rashid et al., 2022). Similarly, (Jabran, 2018) reported that allelochemicals could not be compared with commercial herbicide however its integration with reduced dose of atrazine could provide promising results in suppressing weeds. According to a study, it is also reported that surface mulches of sorghum, sunflower and parthenium in mutual combination under conventional tillage regime reduced the weed density by $54 \%$ in maize (Rashid et al., 2017).

Tillage is another fundamental tool for weed management. Tillage practices disturb soil, which improves soil aeration and mineralization of organic nitrogen and its availability to plant consumption (Halvorson et al., 2001; Dines et al., 2002). Tillage practices play a dominant role not only to retard the grow of weeds but also disturb the soil structure significantly and 
hence could be considering an effective weed control tool. (Mohler and Galford, 1997). Keeping view the important of allelochemicals and tillage for weed management strategies, the current study was design to find out the most effective weed control treatment in relation to different tillage regimes.

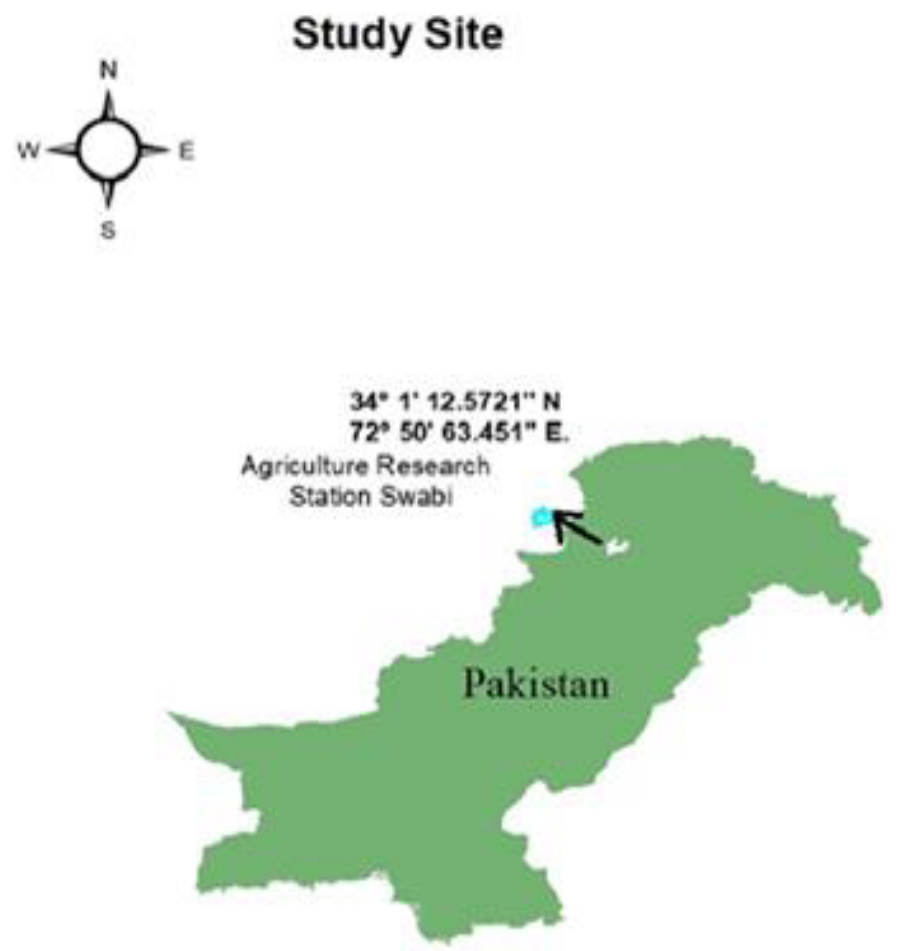

\section{$\begin{array}{lllll}0 & 90180 & 360 & 540 & 720\end{array}$}

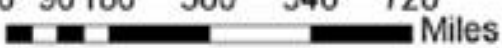

Figure 1: Agriculture research station Swabi, Khyber Pakbtunkhwa, Pakistan.

\section{Materials and Methods}

Experiments were carried out at Agriculture Research Station Swabi, Khyber Pakhtunkhwa, Pakistan (Figure 1) during spring 2014 and subsequently repeated in 2015 . Swabi city is $340 \mathrm{~m}$ above the sea level having Latitude of $34^{\circ} 06^{\prime} 60.00^{\prime \prime} \mathrm{N}$ and Longitude of $72^{\circ}$ 27' 59.99" E. Climate of Swabi is classified as humid subtropical climate $\{($ Koppen Cwa) (Figure 2)\}. Experiments were carried out at silt loam soil in RCBD with split plot arrangements having 3 replications and were comprised of three (03) main plots assigned to different tillage regimes (MT, CT, and DT) and 12 sub-plots assigned to various weed control (WC) treatments. Net plot size of each sub plot was $3 \mathrm{~m}$ x $2 \mathrm{~m}$. Both years same field having same locations for each main plots and sub plots were used. Recommended seed rate of maize @ $25 \mathrm{~kg} \mathrm{ha}^{-1}$, row to row distance of $75 \mathrm{~cm}$ and plant to plant distance was 15 $\mathrm{cm}$ maintained. Soil of experimental site was analysed prior to maize seed sowing. Soil samples were collected from top $15 \mathrm{~cm}$ soil and analysed for physicochemical properties. The soil was silt loamy with $(15.11,59.98,21.6,0.69$, and 0.026$) \%$ of Clay, silt, sand, organic matters and total nitrogen respectively. Available Phosphorus and extractable potasium was 4.16 and 103 ( $\mathrm{mg} \mathrm{kg}^{-1}$ soil) respectively. $\mathrm{pH}$ value was 7.61 and $\mathrm{EC}$ was 0.06 (d Sm-1).

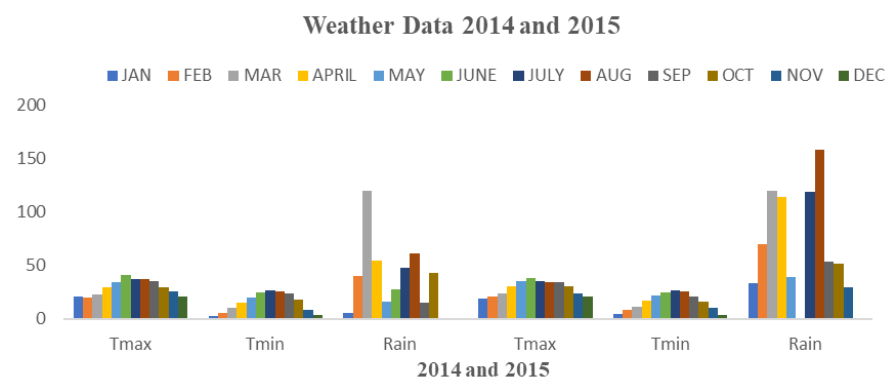

Figure 2: Metrological data 2014 and 2015.

Operation of different tillage regimes were carried out on $1^{\text {st }}$ March 2014 and $7^{\text {th }}$ March 2015 respectively. The seeds of maize hybrid "Pioneer 3025" was carefully sown manually both the years exactly in the same plot (5 $5^{\text {th }}$ March 2014 and $11^{\text {th }}$ March 2015). All required cultural practices and inputs (fertilizers and irrigation water) were applied uniformly to all sub plots. Allelopathic plant species viz sorghum, sunflower and parthenium were collected, cleaned, and chaffed into 3-4 $\mathrm{cm}$ pieces. Species pieces dried in over for 72 hours at $65^{\circ} \mathrm{C}$ (Kenton; KH-120AS) and then were ground. Plant species powder were saturated in distilled water 1:10 (w/v) for 48 hours. Extracts were filtered through muslin cloth to obtain respective aqueous extracts (Cheema and Khaliq, 2000). Before application in the site, quarter dose of atrazine @ $0.125 \mathrm{~kg}$ a.iha ${ }^{-1}$ ) was integrated with each water extract treatment. All water extracts treatments, atrazine @ $0.50 \mathrm{~kg} \mathrm{a.i} \mathrm{ha}{ }^{-1}$ and atrazine @ $0.50 \mathrm{~kg} \mathrm{a.i} \mathrm{ha}{ }^{-1}$ were applied at pre-emergence stage ( $7^{\text {th }}$ March 2014 and $13^{\text {th }}$ March 2015 respectively). For surface mulches, the collected plant species pieces $(3-4 \mathrm{~cm})$ were kept in labelled bags under shaded area. Mulch materials were incorporated with each other's as per experimental treatments and applied in their respective sub plots on 16th March 2014 and 22 ${ }^{\text {nd }}$ March 2015 after maize seed emergence. Data was recorded on dry Biomass of weeds 60 days after sowing (DAS) (5 $5^{\text {th }}$ May 2014 and $11^{\text {th }}$ May 2015 respectively), leaf area $\left(\mathrm{cm}^{2}\right),\left(25^{\text {th }}\right.$ May 2014 and 31 ${ }^{\text {st }}$ May 2015 respectively), leaf area index (\%) 25 $5^{\text {th }}$ June 2014 and 31 $31^{\text {st }}$ June 2015 respectively) and stover yield $\left(\mathrm{Kg} \mathrm{ha}^{-1}\right)$ was recorded on $25^{\text {th }}$ 
Table 1: Tillage and various weed control treatments details.

$\begin{array}{ll}\text { Tillage codes } & \text { Factor-A (Tillage regimes) } \\ \text { MT } & \text { Minimum tillage (rotavator + planking) } \\ \text { CT } & \text { Conventional tillage \{tine plough (twice) + planking\} } \\ \text { DT } & \text { Deep tillage (chisel plough + tine plough + planking) } \\ \text { WCT codes } & \text { Factor-B (Weed control treatments) } \\ \text { T1 } & \text { Sorghum + sunflower (WE) @ 15L each + atrazine @ 1/4th of recommended dose of atrazine (Pre emergence). } \\ \text { T2 } & \text { Sorghum + parthenium(WE) @ 15L each + atrazine @ 1/4th of recommended dose of atrazine (Pre emergence). } \\ \text { T3 } & \text { Sunflower + parthenium (WE) @ 15L each + atrazine @ 1/4th of recommended dose of atrazine (Pre-emer- } \\ & \text { gence). } \\ \text { T4 } & \text { Sorghum + sunflower + parthenium (WE) @ 15L each + atrazine @ 1/4th of recommended dose of atrazine } \\ \text { T5 } & \text { (Pre-emergence). } \\ \text { T6 } & \text { Sorghum + sunflower (SM) each @ 6 Mg ha }{ }^{-1} \text { at 3-4 leaf stage of maize. } \\ \text { T7 } & \text { Sorghum + parthenium (SM) each @ 6 Mg ha }{ }^{-1} \text { at 3-4 leaf stage of maize. } \\ \text { T8 } & \text { Sunflower + sorghum + parthenium (SM) each @ 6 Mg ha }{ }^{-1} \text { at 3-4 leaf stage of maize. } \\ \text { T9 } & \text { Sorghum + sunflower + parthenium (S.M) each @ 6 Mg ha }{ }^{-1} \text { at 3-4 leaf stage of maize. } \\ \text { T10 } & \text { Atrazine @ 0.50 kg a.i ha }{ }^{-11} / 4 \text { th of recommended dose alone (Pre emergence). } \\ \text { T11 } & \text { Atrazine @ 0.50 kg a.i ha }{ }^{-1} \text { or recommended rate (Pre emergence). } \\ \text { T12 } & \text { Hand weeding } 30 \text { days after germination of } Z \text {. mays (once) } \\ & \text { Weedy check }\end{array}$

July 2014 and $30^{\text {th }}$ July 2015, respectively). The recorded data were statistically analyzed (year wise as well as combined over years) and subjected to ANOVA procedure using Statistix 8.1 software $\{$ (www. statistix.com) (support@statistix.com)\}, Means were separated by using $\mathrm{LSD}_{0.05}$ test (Steel et al., 1997) (Table 1).

\section{Results and Discussion}

\section{Dry biomass (g) of total weeds $60 \mathrm{DAS}$}

Statistical analysis of the data revealed that tillage, weed control treatments and their interaction (Tillage $\mathrm{x}$ WC treatments) significantly affected dry biomass (g) of weeds 60 DAS (Table 2). Pooled data recorded for tillage regimes showed that maximum dry biomass (567 g) was observed in MT, whereas the minimum $(514 \mathrm{~g})$ was recorded in DT. Lower dry weight in DT was due to maximum soil disturbance till $45 \mathrm{~cm}$ depth, whereas in MT the soil was disturbed only till 5-6 cm depth. These results are confirmatory to the findings of who reported that in Intensity of tillage effect the dry biomass of weeds. However, in 2014 maximum dry biomass (711 g) was recorded in MT whereas during 2015 it was recorded in MT. this could possibly be due to the fact that unterminated seeds available on topsoil may undergo inside which have germinated during 2015. Among various WC treatments, maximum (730 g) was recorded in weedy check treatment, whereas the minimum dry biomass $(339 \mathrm{~g})$ was recorded in T8. In T10 treatment (atrazine), dry biomass of weeds was (479 $\mathrm{g}$ ) which shows that efficacy of atrazine in reducing dry biomass of weeds were less than T8. Mulches plays an important role in reducing dry biomass of weeds by retarding the germination and growth of weed species through physical coverage of soil. Allelochemicals reported in these mulch materials (Allelopathic plants) could also be accountable for reducing dry biomass of weeds through release of allelochemicals by leaching which could retard the germination and growth of weed species. Among the interaction means (Figure 3) minimum dry biomass of weeds $(84.17 \mathrm{~g})$ was recorded in T7 under DT, hence based on our study objective, T7 $\{$ Sunflower + Parthenium (SM)\} was the most effective treatment in reducing dry biomass of weeds 60 DAS. 
Table 2: Dry biomass $60 \mathrm{DAS}(\mathrm{g})$ and leaf area $\left(\mathrm{cm}^{2}\right)$ in spring planted maize as affected by integration of various allelopathic extracts and mulch treatments under different tillage regimes.

\begin{tabular}{|c|c|c|c|c|c|c|}
\hline \multirow[b]{2}{*}{ Tillage regimes } & \multicolumn{3}{|c|}{ Dry Biomass 60 DAS } & \multicolumn{3}{|c|}{ Leaf Area $\left(\mathrm{cm}^{2}\right)$} \\
\hline & 2014 & 2015 & Pooled & 2014 & 2015 & Pooled \\
\hline MT & $711 \mathrm{a}$ & $423 \mathrm{~b}$ & $567 \mathrm{~A}$ & $1069 \mathrm{~b}$ & $2141 \mathrm{~b}$ & $1605 \mathrm{~B}$ \\
\hline $\mathrm{CT}$ & $684 \mathrm{~b}$ & $443 \mathrm{a}$ & $564 \mathrm{~B}$ & $1426 \mathrm{a}$ & $2895 \mathrm{a}$ & $2160 \mathrm{~A}$ \\
\hline DT & $671 \mathrm{c}$ & $357 \mathrm{c}$ & $514 \mathrm{C}$ & $1487 \mathrm{a}$ & $3005 \mathrm{a}$ & $2246 \mathrm{~A}$ \\
\hline LSD $5 \%$ & 0.68 & 0.25 & 0.35 & 172.6 & 386.59 & 175.82 \\
\hline \multicolumn{7}{|c|}{ Weed Control Treatments } \\
\hline $\mathrm{T} 1$ & $835 \mathrm{c}$ & 586 a & $710 \mathrm{~B}$ & 1366 ce & 2758 de & $2062 \mathrm{D}$ \\
\hline $\mathrm{T} 2$ & $821 \mathrm{e}$ & $463 \mathrm{~d}$ & $642 \mathrm{E}$ & $1393 \mathrm{~cd}$ & 2814 bd & $2108 \mathrm{CD}$ \\
\hline T3 & $817 \mathrm{f}$ & $540 \mathrm{~b}$ & $678 \mathrm{D}$ & $1269 \mathrm{df}$ & $2563 \mathrm{ef}$ & $1916 \mathrm{E}$ \\
\hline $\mathrm{T} 4$ & $832 \mathrm{~d}$ & $452 \mathrm{f}$ & $642 \mathrm{E}$ & $1251 \mathrm{ef}$ & $2528 \mathrm{ef}$ & $1889 \mathrm{E}$ \\
\hline T5 & $483 j$ & $290 \mathrm{j}$ & $387 \mathrm{~J}$ & $1467 \mathrm{bc}$ & $2963 \mathrm{bd}$ & $2215 \mathrm{BC}$ \\
\hline T6 & $461 \mathrm{k}$ & $328 \mathrm{i}$ & $395 \mathrm{H}$ & $1393 \mathrm{~cd}$ & $2814 \mathrm{~cd}$ & $2104 \mathrm{CD}$ \\
\hline T7 & $533 \mathrm{i}$ & 2461 & $389 \mathrm{I}$ & $1598 \mathrm{a}$ & $3227 \mathrm{a}$ & $2412 \mathrm{~A}$ \\
\hline T8 & 4161 & $262 \mathrm{k}$ & $339 \mathrm{~K}$ & $1554 \mathrm{ab}$ & $3036 \mathrm{ac}$ & $2295 \mathrm{AB}$ \\
\hline T9 & $914 \mathrm{~b}$ & $455 \mathrm{e}$ & $684 \mathrm{C}$ & $1091 \mathrm{~g}$ & $3018 \mathrm{~g}$ & $1650 \mathrm{~F}$ \\
\hline T10 & $593 \mathrm{~g}$ & $366 \mathrm{~h}$ & $479 \mathrm{G}$ & $1456 \mathrm{bc}$ & $2263 \mathrm{ab}$ & $2261 \mathrm{~B}$ \\
\hline T11 & $577 \mathrm{~h}$ & $431 \mathrm{~g}$ & $504 \mathrm{~F}$ & $1217 \mathrm{fg}$ & $2457 \mathrm{fg}$ & $1826 \mathrm{E}$ \\
\hline $\mathrm{T} 12$ & $986 \mathrm{a}$ & $474 \mathrm{c}$ & $730 \mathrm{~A}$ & $871 \mathrm{~h}$ & $1797 \mathrm{~h}$ & $1307 \mathrm{G}$ \\
\hline LSD $5 \%$ & 1.37 & 0.49 & 0.69 & 127.7 & 249.42 & 138.81 \\
\hline Years & 689 & 408 & & 1327.2 B & $2680.4 \mathrm{~A}$ & \\
\hline Tillage $\times \mathrm{T}$ & 0.00 & 0 & 0 & 0 & 0 & 0 \\
\hline
\end{tabular}

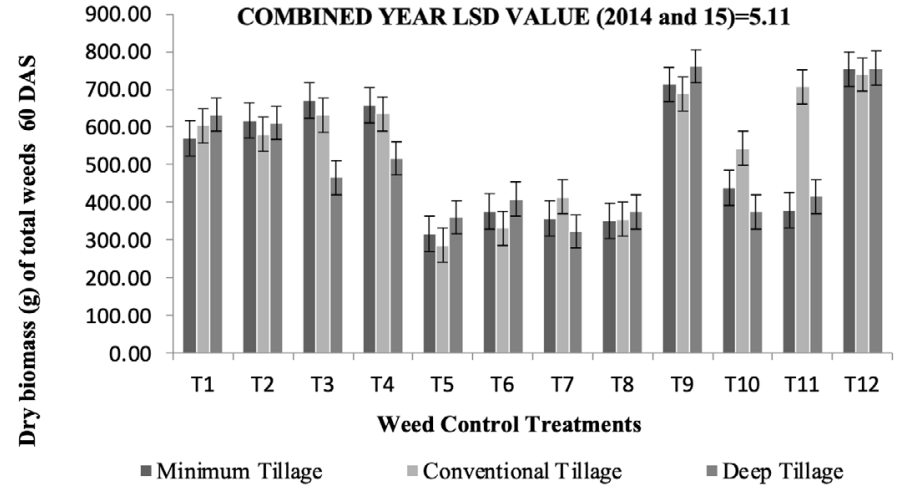

Figure 3: Interaction between tillage and various allelopathic treatments on weed density $60 \mathrm{DAS}$.

\section{Leaf area $\left(\mathrm{cm}^{2}\right)$ Plant ${ }^{-1}$}

Analysis of the data showed that Tillage, WC treatments, and interaction between Tillage $\mathrm{x}$ WC treatments significantly affected leaf area of the maize crop (Table 2). Combined data of two years for tillage factor showed that maximum leaf area $\left(2246 \mathrm{~cm}^{2}\right)$ was recorded in DT followed by CT with $\left(2160 \mathrm{~cm}^{2}\right)$ whereas the minimum $\left(1605 \mathrm{~cm}^{2}\right)$ was recorded in MT regime. Among various WC treatments significant result was shown by $\mathrm{T} 7$ where maximum leaf area $\left(2412 \mathrm{~cm}^{2}\right)$ was recorded and followed by T8 with $\left(2295 \mathrm{~cm}^{2}\right)$. T10 (atrazine) treatment leaf area recorded was $2261\left(\mathrm{~cm}^{2)}\right.$ which was significantly minimum to those of T7 and T8 treatments. Furthermore, Leaf area mean value $\left(2680.4 \mathrm{~cm}^{2}\right)$ was maximum during 2015 as compared to $\left(1327.2 \mathrm{~cm}^{2}\right)$ recorded in 2014 .

Maximum leaf area during the 2015 could be attributed due to better weed control in T7 and increasing rainfall in April-May 2015 (Figure 1.2). Among the interaction means (pooled data), maximum leaf area $\left(2938 \mathrm{~cm}^{2}\right)$ was recorded in T7 under DT regime (Figure 4). Whereas for T10 (atrazine) treatment maximum value of leaf area $\left(2618 \mathrm{~cm}^{2}\right)$ was recorded under DT which is still significantly lower than to that of T7 under DT regime. It should be considered a positive indicator where we could replace atrazine with T7 treatment under DT regime as a part of sustainable weed management strategy. 
Table 3: Leaf area index and stover yield $\left(\mathrm{kg}^{\mathrm{h}} \mathrm{ha}^{-1}\right)$ in spring planted maize as affected by integration of various allelopathic extracts and mulch treatments under different tillage regimes.

\begin{tabular}{|c|c|c|c|c|c|c|}
\hline \multirow[b]{2}{*}{ Tillage regimes } & \multicolumn{3}{|c|}{ Leaf Area Index } & \multicolumn{3}{|c|}{ Stover Yield } \\
\hline & 2014 & 2015 & Pooled & 2014 & 2015 & Pooled \\
\hline MT & $1.07 \mathrm{~b}$ & $2.13 \mathrm{~b}$ & $1.61 \mathrm{~B}$ & 8416 & 7792 b & 8104 B \\
\hline $\mathrm{CT}$ & $1.42 \mathrm{a}$ & $2.89 \mathrm{a}$ & $2.16 \mathrm{~A}$ & 9699 & $9986 \mathrm{ab}$ & 9843 A \\
\hline DT & $1.49 \mathrm{a}$ & $3.00 \mathrm{a}$ & $2.24 \mathrm{~A}$ & 9830 & $10884 \mathrm{a}$ & $10337 \mathrm{~A}$ \\
\hline LSD $5 \%$ & 0.175 & 0.372 & 0.17 & NS & 2393.3 & 1238 \\
\hline \multicolumn{7}{|c|}{ Weed control treatments } \\
\hline $\mathrm{T} 1$ & $1.37 \mathrm{ce}$ & $2.76 \mathrm{ce}$ & $2.06 \mathrm{DE}$ & $8637 d$ & 9016 a & $8826 \mathrm{D}$ \\
\hline $\mathrm{T} 2$ & 1.38 ce & $2.81 \mathrm{bd}$ & $2.09 \mathrm{CD}$ & $9585 \mathrm{ad}$ & 9581 a & $9583 \mathrm{BD}$ \\
\hline T3 & $1.27 \mathrm{df}$ & $2.59 \mathrm{df}$ & $1.93 \mathrm{EF}$ & 9408 bd & $10336 \mathrm{a}$ & $9872 \mathrm{AC}$ \\
\hline $\mathrm{T} 4$ & $1.26 \mathrm{ef}$ & $2.53 \mathrm{ef}$ & $1.89 \mathrm{~F}$ & $9670 \mathrm{ad}$ & $9169 \mathrm{a}$ & $9419 \mathrm{BD}$ \\
\hline T5 & $1.46 \mathrm{bc}$ & $2.96 \mathrm{bc}$ & $2.206 \mathrm{BC}$ & $8569 \mathrm{~d}$ & 10099 a & $9334 \mathrm{BD}$ \\
\hline T6 & $1.39 \mathrm{~cd}$ & $2.81 \mathrm{bd}$ & $2.10 \mathrm{CD}$ & 9989 ac & $10514 \mathrm{a}$ & $10251 \mathrm{AB}$ \\
\hline T7 & $1.60 \mathrm{a}$ & $3.22 \mathrm{a}$ & $2.41 \mathrm{~A}$ & $10530 \mathrm{ab}$ & $10155 \mathrm{a}$ & $10342 \mathrm{AB}$ \\
\hline T8 & $1.56 \mathrm{ab}$ & $3.03 \mathrm{ab}$ & $2.29 \mathrm{AB}$ & $10908 \mathrm{a}$ & $10501 \mathrm{a}$ & $10704 \mathrm{~A}$ \\
\hline T9 & $1.10 \mathrm{~g}$ & $2.19 \mathrm{~g}$ & $1.64 \mathrm{G}$ & $8812 \mathrm{~cd}$ & 9391 a & $9102 \mathrm{CD}$ \\
\hline $\mathrm{T} 10$ & $1.46 \mathrm{bc}$ & $3.06 \mathrm{ab}$ & $2.26 \mathrm{~B}$ & 9368 bd & 9864 a & $9616 \mathrm{BD}$ \\
\hline $\mathrm{T} 11$ & $1.22 \mathrm{fg}$ & $2.42 \mathrm{fg}$ & $1.82 \mathrm{~F}$ & 9191 bd & $9523 \mathrm{a}$ & $9357 \mathrm{BD}$ \\
\hline $\mathrm{T} 12$ & $0.88 \mathrm{~h}$ & $1.73 \mathrm{~h}$ & $1.31 \mathrm{H}$ & 7113 e & $6342 \mathrm{~b}$ & $6727 \mathrm{E}$ \\
\hline LSD $5 \%$ & 0.131 & 0.254 & 0.14 & 1341.8 & 1594.8 & 1032.5 \\
\hline Years & $1.33 \mathrm{~B}$ & $2.68 \mathrm{~A}$ & & $9540.8 \mathrm{~A}$ & 9315 A & \\
\hline Tillage $\times \mathrm{T}$ & 0 & 0 & 0 & NS & 0.04 & 0.02 \\
\hline
\end{tabular}

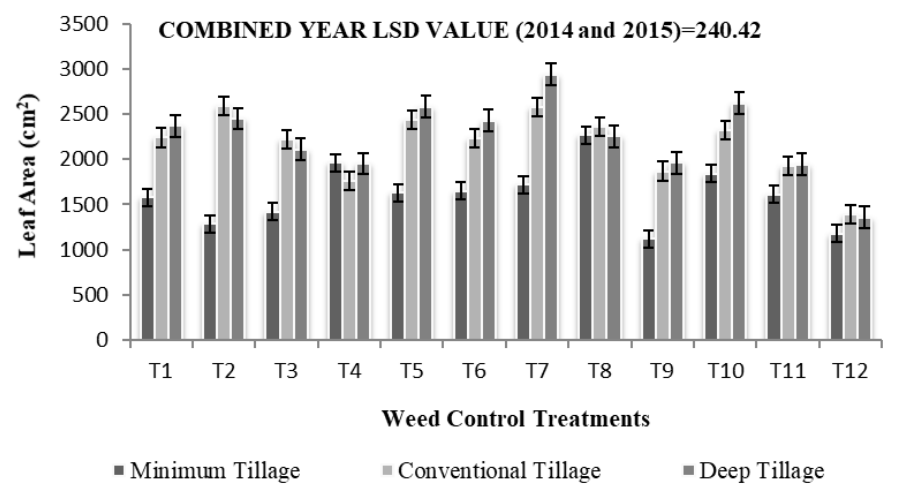

Figure 4: Interaction between tillage and various allelopathic treatments on leaf area $\left(\mathrm{cm}^{2}\right)$.

\section{Leaf area index}

Data analysis of both years revealed that Tillage, various WC treatments, and interaction (Tillage $\mathrm{x}$ WC treatments) significantly affected Leaf area Index (Table 3). Pooled data of both years (2014 and 2015) recorded for tillage regimes indicated that maximum leaf area index (2.24) was recorded in DT followed by CT with (2.16), whereas the minimum value (1.61) was recorded in MT. Similar trends were found in both years of study. Analysis of two years mean data recorded for WC treatments showed that among all WC treatments, maximum Leaf area Index (2.41) was recorded in T7, followed by T8 with (2.29), however the efficacy of T10 (atrazine) was very close with value recorded (2.26). Leaf area index (2.68) during 2015 was maximum as compared to (1.33) recorded in 2014. Among the interaction means, maximum leaf area Index (2.93) was recorded in T7 under DT regime (Figure 5). Whereas T10 (atrazine) treatment showed its maximum value (2.62) for LAI under DT regime which is still less than that of T7 under DT regime.

\section{Stover yield $\left(\mathrm{kg} \mathrm{ha}^{-1}\right)$}

Statistical analysis of pooled data showed that Tillage, WC treatments and Interaction (Tillage $x$ WC treatments) significantly affected Stover yield of maize (Table 3). Analysis of two years averaged data showed that maximum value of Stover yield $\left(10337 \mathrm{~kg} \mathrm{ha}^{-}\right.$ 1) was recorded in DT followed by CT with (9843 $\left.\mathrm{kg} \mathrm{ha}{ }^{-1}\right)$, whereas the minimum (8104 $\mathrm{kg} \mathrm{ha}^{-1}$ ) was recorded in MT. Tillage effect was found non-significant during 2014. Among various WC treatments maximum Stover yield (10702 $\left.\mathrm{kg} \mathrm{ha}^{-1}\right)$ was recorded in T8, followed by T7 and T6 with values $(10342 \mathrm{~kg}$ $\left.\mathrm{ha}^{-1}\right)$ and $\left(10251 \mathrm{~kg} \mathrm{ha} \mathrm{h}^{-1}\right)$ respectively. For T10 (atrazine) treatment value of stover yield recorded was December 2021 | Volume 37 | Issue 4 | Page 1328 
$\left(9616 \mathrm{~kg} \mathrm{ha}^{-1}\right)$ which is still lower than to those of T8, T7 and T6 treatments. Among the interaction means (Tillage $\times \mathrm{WC}$ treatments) maximum stover yield (12426 kg ha-1) was recorded in T8 under CT regime (Figure 6). Whereas at T10 (atrazine) treatment maximum value (10653 $\left.\mathrm{kg} \mathrm{ha}^{-1}\right)$ was recorded under DT regime which is still lower than that of T8 under CT regime.

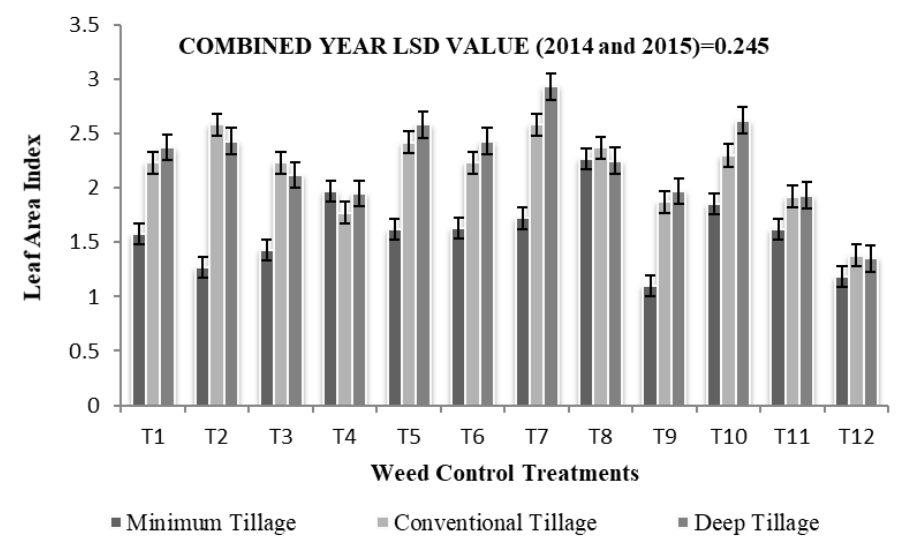

Figure 5: Interaction between tillage and various allelopathic treatments on leaf area index.

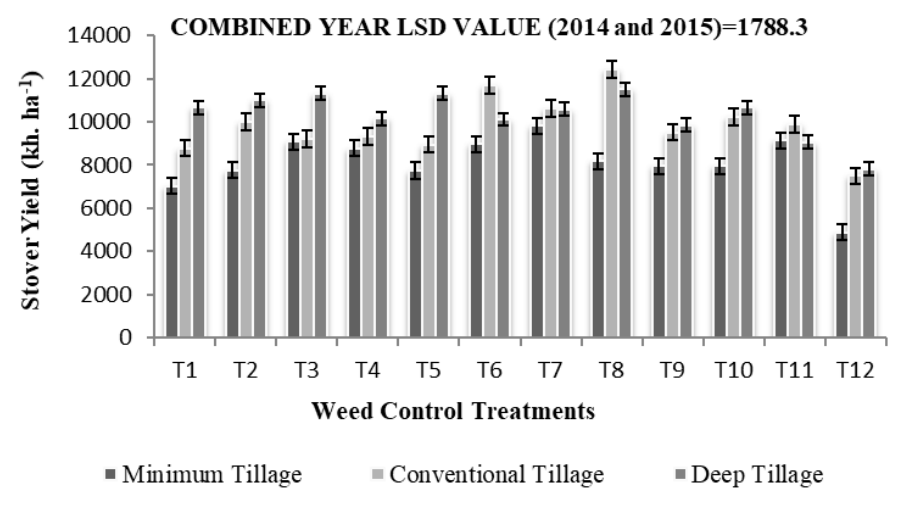

Figure 6: Interaction between tillage and various allelopathic treatments on stover yield $\left(\mathrm{kg}^{\mathrm{b}} \cdot \mathrm{ha} \mathrm{w}^{-1}\right)$.

Research findings for different tillage regimes are in line with the results obtained by (Khattak et al., 2005) who stated that frequency of tillage is inversely proportional to weed density. With increased frequency in deep tillage followed by conventional significantly reduced the weed densities of all species possibly due to destruction of annual as well as perennial germinated weeds in the soil which ultimately leads to reduced dry biomass of weed species. Similarly, (Rashid et al., 2017; Rashid et al., 2019 and Rashid et al., 2020) also confirmed that reduced weed densities, dry biomass of weed species were observed in DT (Deep Tillage) followed by CT (Conventional Tillage) when compared to MT (minimum tillage). In MT the soil was not tilled to the greater extend as compared to DT and CT and hence the germination of weed seeds were recorded more. According to the results obtained by (Cardina et al., 1991) it is also confirmed that in minimum tillage dry biomass of weeds could be reduced.

Among the various allelopathic treatments total dry weed biomass 60 DAS were expressively affected by all applied treatments as compared to T12 (weedy check treatment). Our findings suggest that T1, T2, T3 and T4 (allelopathic extracts in combination with atrazine@0.125 kg a.iha ${ }^{-1}$ ) could provide promising results when compared to T12 (weedy check), however, efficacy of such extracts was found less than that of T10 (atrazine @ $0.50 \mathrm{~kg} \mathrm{a.iha}^{-1}$ ) in suppressing dry biomass of total weeds 60 DAS. Results indicated that efficacy of T5, T6, T7 and T8 (allelopathic plant residues applied as surface mulches) were found more effective when compared to T10 and rest of the treatments. However, T10 treatment was more suppressive in reducing total dry biomass $60 \mathrm{DAS}$ as compared to $\mathrm{T} 1, \mathrm{~T} 2, \mathrm{~T} 3$ and $\mathrm{T} 4$.

Less efficacy of T1, T2, T3 and T4 treatments (water extracts integrated with atrazine @ $0.125 \mathrm{~kg} \mathrm{a}$ iha $^{-1}$ as compared to T10 (atrazine @ $0.50 \mathrm{~kg}$ a.i ha ${ }^{-1}$ ) could possibly be due to several biotic and abiotic factors e.g Light, soil, and temperature etc. (Hoagland and Williams, 1985). It could also be a possible reason that activity of various allelochemicals may change due to soil physicochemical and biological properties during leaching process. Our results are in line with the findings of (Rashid et al., 2017; Rashid et al., 2019 and Rashid et al., 2022) who stated that for various parameters the efficacy of allelopathic plants water extracts (Sorghum, sunflower and parthenium) integrated with atrazine @ $0.125 \mathrm{~kg}$ a.i ha ${ }^{-1}$ was less than that of atrazine treatment applied @ $0.50 \mathrm{~kg}$ a.i $\mathrm{ha}^{-1}$. Furthermore, the significant effect of Sorghum, sunflower and parthenium plant residues as a surface mulches to reduce dry biomass 60 DAS of total weeds are encouraging findings when compared to other treatments. The significant effect of surface mulching could be due to the physical coverage of soil surface and partially could be due to the reported allelochemicals in these allelopathic plant species. Mulches covered the soil surface and reduced the penetration of sunlight required for the photosynthetic process of weed species and increase water holding capacity which ultimately increase the availability of nutrient in soil and the same time retard the 
growth of weed species. Our results are confirmatory to the findings of Erenstien (2002) who reported that surface mulch application reduced the dry biomass of weed species due to allelopathic spectacles. Similarly, (Kamara et al., 2002) reported his research findings stating that surface mulches significantly reduce the penetration of light and disturb the photosynthetic process in weed species. Apart from the physical coverage, these surface mulches impact the dry biomass of weeds through the phytotoxic activities reported in these plant species (Sorghum, sunflower and parthenium). Sorgoleone in sorghum bicolor responsible for inhibiting the electron transport in both photosynthesis and respiration (Nimbal et al., 1996), phenolics responsible for reduction of chlorophyll content (Inderjit and Dakshini, 1992), and other compounds like vanillic and ferulic acids reported in parthenium, sorghum and sunflower plants are responsible for DNA and RNA synthesis (Baziramakenga et al., 1997).

Among all the treatments encouragingly significant results for dry biomass 60 DAS of total weeds were recorded in T8 (sorghum + sunflower + parthenium (S.M) each@6 Mg ha ${ }^{-1}$ at 3-4 leaf stage of maize) treatment as compared T10 (atrazine @ $0.50 \mathrm{~kg}$ a.iha ${ }^{-1}$ ), T1, T2, T3 and T4 (water extracts combine with atrazine @ $0.125 \mathrm{~kg} \mathrm{a}$ iha $\left.^{-1}\right), \mathrm{T} 11$ (hand weeding) and T12 (weedy check) treatments.

Size of leaf is directly linked to plant food through photosynthesis; hence it is considering a basic photosynthetic machinery for the preparation of plant food. It is also known that higher the area of leave will prepare more food for the plant, which will be transfer to other parts of plant body. The classification of Physiological plant growth is referred to leaf area index. Higher value of LAI shows higher dry matter content of the crop. Analysis of the data showed that among the different tillage regimes higher leaf area $\left(\mathrm{m}^{2}\right)$ and leaf area index (LAI) was recorded in DT followed by CT, whereas the lower leaf area $\left(\mathrm{m}^{2}\right)$ and LAI of maize plants were recorded in MT. The reason for higher leaf area $\left(\mathrm{m}^{2}\right)$ and leaf area index (LAI) could be attributed to well development of root which may led to faster flow of water and nutrients from soil to the maize crop. Our results for tillage regimes are confirmatory to the findings of Tangadulratana (1985) who reported that conventional tillage was superior to zero tillage regarding the leaf area and leaf area index (LAI). Similarly, our results are also in close similarity to the findings of Karunatilake (2000) who reported that higher leaf area of maize plants was found in conventional tillage as compared to no tillage (zero tillage).

Analysis of the data revealed that higher leaf area $\left(\mathrm{m}^{2}\right)$ and leaf area index (LAI) was found in T6 (sorghum+ parthenium (SM) each @6 Mg ha ${ }^{-1}$ at 3-4 leaf stage of maize)which was significantly higher than T9 (atrazine@0.125 kg a.iha ${ }^{-1}$ ) and T1,T2,T3, and T4 (water extracts integrated with atrazine @ $0.125 \mathrm{~kg}$ a.iha $\left.\mathrm{T}^{-1}\right)$ treatments. The higher leaf area $\left(\mathrm{m}^{2}\right)$ in $\mathrm{T} 5$, T6, T7 and T8 (all mulch treatments) might be attributed due to effective weed control which provided favorable condition for leaf developments.

Data recorded for stover yield $\left(\mathrm{kg} \mathrm{ha} \mathrm{g}^{-1}\right)$ showed that higher value was recorded under DT followed by CT, whereas the lowest stover yield $\left(\mathrm{kg} \mathrm{ha}^{-1}\right)$ was recorded in MT. The reason for higher stover yield in DT and CT could be due to the improved soil aeration which may allow roots to utilize the available nutrients required for good crop stand. Among the various weed control measures, all the allelopathic treatments had significant effect on stover yield $\left(\mathrm{kg} \mathrm{ha}^{-1}\right)$ when compared to weedy check treatment. Efficacy of T8 (sorghum + sunflower + parthenium (SM) each @6 $\mathrm{Mg} \mathrm{ha}{ }^{-1}$ at 3-4 leaves stage of maize)had promising effect on weed suppression and thus contributed toward maximum yield of stover. Our results are in line with the findings obtained by (Nawab et al.,1999) who reported that mulching increased the stover yield significantly.

\section{Conclusions and Recommendations}

Integration of tillage regimes and various allelopathic treatments had significant effect on tested parameters. However, the efficacy of T5, T6, T7 and T8 (surface mulches) was more pronounced than T10 (atrazine foliar application @ $0.50 \mathrm{~kg} \mathrm{a.i} \mathrm{ha}{ }^{-1}$ ) andT1, T2, T3 and T4(allelopathic plants water extracts combined with atrazine @ $0.125 \mathrm{~kg}$ a.i ha ${ }^{-1}$ ). Data obtained for the interaction effect showed that T8 under CT (Sorghum +sunflower + parthenium (S.M) each @6 $\mathrm{Mg} \mathrm{ha}{ }^{-1}$ at 3-4 leaf stage of maize under conventional tillage) produced the maximum stover yield of 12426 $\mathrm{kg} \cdot \mathrm{ha}^{-1}$. Hence it is suggested that T8 under CT could possibly be an alternative to T10 for sustainable weed management in maize. Keeping in view the sustainability concept, further studies are suggested to investigate the allelochemicals effect of these selected plant 
species on soil microbial activities.

\section{Abbreviations}

\begin{tabular}{ll} 
Abbreviations & Descriptions \\
IWM & Integrated Weed Management \\
RCBD & Randomized Complete Block Design \\
@ & At the rate \\
A.i & Active ingredients \\
DAS & Days after sowing \\
MT & Minimum Tillage \\
CT & Conventional Tillage \\
DT & Deep Tillage \\
SM & Surface mulches \\
WE & Water extracts \\
WCT & Weed control treatments \\
LSD & Least significant difference \\
\hline
\end{tabular}

\section{Acknowledgements}

This study is a part of $\mathrm{PhD}$ dissertation, submitted to the University of Haripur, Pakistan by the principal author and very thankful to HEC Pakistan for granting fully funded scholarship under "HEC Indigenous 5000 PhD Fellowship Program Phase-II, Batch-I". The principal author is also thankful to the Director and Research officers of Agriculture Research Station, Swabi for their logistics and technical support.

\section{Novelty Statement}

The innovative idea of integration approach for sustainable weed management in maize.

\section{Author's Contribution}

Haroon Ur Rashid: Field research, designing, data collection and wrote draft of the manuscript.

Nazia Tahir: Data analysis and mapping.

M. Zamin: Technical review and guidelines.

Naveed Shahzed: Helped in data collection.

Aman U1lah: Helped in data analysis.

Bibi Zainub: Data formatting and software support. Farooq Azam: Technical review and corrections.

\section{References}

Baziramakenga, R., Leroux, G.D., Simard, R.R. and Nadeau, P. 1997. Allelopathic effects of phenolic acids on nucleic acid and protein levels in soybean seedlings. Canadian J. Botany. 75(3): 445-450. https://doi.org/10.1139/b97-047

Cardina, J., Regnier, E. and Harrison, K. 1991. Long-term tillage effects on seed banks in three Ohio soils. Weed Sci. 186-194. https://doi.org/10.1017/S0043174500071459

Cheema, Z.A. and Khaliq, A. 2000. Use of sorghum allelopathic properties to control weeds in irrigated wheat in a semi arid region of Punjab. Agric. Ecosyst. Environ. 79(23):105-112. https://doi.org/10.1016/S01678809(99)00140-1

Dinnes, D.L., Karlen, D.L., Jaynes, D.B., Kaspar, T.C., Hatfield, J.L., Colvin, T.S. and Cambardella,C.A.2002. Nitrogen management strategies to reduce nitrate leaching in tiledrained Midwestern soils. Agron. J. 94(1): 153171. https://doi.org/10.2134/agronj2002.0153

Erenstein, O. 2002. Crop residue mulching in tropical and semi-tropical countries: An evaluation of residue availability and other technological implications. Soil Tillage Res. 67(2): 115-133. https://doi.org/10.1016/ S0167-1987(02)00062-4

Fahad, S., Hussain, S., Saud, S., Hassan, S., Muhammad, H., Shan, D., Chen, C., Wu, C., Xiong, D., Khan, S.B. and Jan, A. 2014. Consequences of narrow crop row spacing and delayed Echinochloacolona and Trianthemaportulacastrum emergence for weed growth and crop yield loss in maize. Weed Res. 54(5): 475-483. https://doi. org/10.1111/wre.12104

GoP. 2020. Pakistan Economic Survey 2019-20. Economic Advisors Wing, Finance Division, Government of Pakistan, Islamabad.

Halvorson, A.D., Wienhold, B.J. and Black, A.L. 2001. Tillage and nitrogen fertilization influence grain and soil nitrogen in an annual cropping system. Agron. J. 93(4): 836-841. https://doi.org/10.2134/agronj2001.934836x

Hassan, G., Rashid, H.U., Amin, A., Khan, I.A. and Shehzad, N. 2018. Allelopathic effect of Parthenium hysterophorus on germination and growth of some important crops and weeds of economic importance. https://doi.org/10.1590/ s0100-83582018360100132

Heap,I.2020.The International Survey of Herbicide Resistant Weeds. - www.weedscience.org (accessed on April 2, 2020).

Heap, I., Duke, S.O. 2018. Overview of glyphosate- 
resistant weeds worldwide. Pest Mgt. S c i . 74(5): 1040-1049. https://doi.org/10.1002/ ps. 4760

Hoagland, R.E. and Williams, R.D. 1985. The influence of secondary plant compounds on the associations of soil microorganisms and plant roots. Am. Chem. Soc. 268: 301-325. https:// doi.org/10.1021/bk-1985-0268.ch020

Inderjit, R.K. and Dakshini, K.M.M. 1992. Interference potential of Pluchea lanceolata (Asteraceae): growth and physiological responses of asparagus bean, Vigna unguiculata var. sesquipedalis. Am. J. Bot., 79 (9): 977-981

Jabran, K. 2018. Tank mixing of allelopathic crop water extracts with pendimethalin helps in the management of weeds in canola (Brassica napus) field. Int. J. Agric. Biol., 10(3): 293-296.

Kamara, A.Y., Akobundu, I.O., Chikoye, D. and Jutzi, S.C. 2000. Selective control of weeds in an arable crop by mulches from some multipurpose trees in Southwestern Nigeria. Agroforestry Syst. 50(1): 17-26. https://doi.org/10.1023/A:1006425825597

Karunatilake, U., Van Es, H.M. and Schindelbeck, R.R. 2000. Soil and maize response to plow and no-tillage after alfalfa-to-maize conversion on a clay loam soil in New York. Soil Tillage Res. 55(1-2): 31-42. https://doi.org/10.1016/ S0167-1987(00)00096-9

Khan, M.A.H. and Parvej, M.R. 2010. Impact of conservation tillage under organic mulches on the reproductive efficacy and yield of quality protein maize. J.Agric. Sci. 5(2): 52-63. https:// doi.org/10.4038/jas.v5i2.2782

Khattak, M.K., Khan, M.J., Muhammad, A., Said, W. and Muhammad, R. 2005. Enhancement of wheat yield and yield components by controlling weeds with deep tillage practices under irrigated clay loam soil conditions. Pak. J. Weed Sci. Res. 11(3/4):131-136.

Kumar, R., Kumawat, N., Kumar, S., Singh, A.K. and Bohra, J.S. 2017. Effect of NPKS and Zn fertilization on growth, yield and quality of baby corn-a review. Int. J. Curr. Microbiol Appl. Sci. 6(3): 1392-1428.https://doi.org/10.20546/ ijcmas.2017.603.161

Macías, F.A., Varela, R.M., Torres, A., Galindo, J.L. and Molinillo, J.M. 2002. Allelochemicals from sunflowers: chemistry, bioactivity, and applications. In Chemical Ecology of Plants: Allelopathy in Aquatic and Terrestrial
Ecosystems. Pg\#73-87. Birkhäuser, Basel. https://doi.org/10.1007/978-3-0348-8109$8 \_5$

Mohler,C.L.and Galford,A.E.1997.Weed seedling emergence and seed survival: separating the effects of seed position and soil modification by tillage. Weed Res. 37(3):147- 155 . https:// doi.org/10.1046/j.1365-3180.1997.d01-21.x

Nawab, K., Hatam, M., Khan, B.A., Rasul, K. and Mansoor, M. 1999. Study of some morphological characters in maize as affected by time of weeding and plant spacing. Sarhad J. Agric. 15(1): 21-24

Nimbal, C.I., Pedersen, J.F., Yerkes, C.N., Weston, L.A. and Weller, S.C. 1996. Phytotoxicity and distribution of sorgoleone in grain sorghum germplasm. J. Agric. Food Chem. 44(5): 13431347. https://doi.org/10.1021/jf950561n

Powles, S.B. and Yu, Q. 2010. Evolution in action: plants resistant to herbicides. Annu. Rev. P1. Biol. 61: 317-347. https://doi.org/10.1146/ annurev-arplant-042809-112119

Rashid, H., Khan, M.A., Amin, A., Nawab, K., Hussain, N. and Bhowmik, P.K. 2008. Effect of Parthenium hysterophorus L., root extracts on seed germination and growth of maize and barley. Am. J. Pl. Sci. Biotech. 2(2): 51-55.

Rashid, H., Khan, A., Hassan, G., Munsif, F., Tahir, N., Zamin, M., and Shehzad, N, 2022. Integration of some allelopathic species for weed management in spring planted hybrid maize under different tillage regimes. J. anim. plant sci. 32 (1). (Online) http://www.thejaps. org.pk/Volume/2022/32-01/14.php

Rashid, H.U., Khan, A., Hassan, G., Khan, S.U., Saeed, M., Khan, S.A., Khan, S.M. and Hashim, S. 2020. Weed suppression in maize (Zea mays L.) through the allelopathic effects of sorghum [sorghum bicolor (1.) conard moench.] sunflower (helianthus annuus 1.) and parthenium (parthenium hysterophorus 1.) Plants Appl. Ecol. Environ. Res. 18(4): 5187-5197. https:// doi.org/10.15666/aeer/1804_51875197

Rashid, H.U., Khan, A., Hassan, G., Saeed, M., Khan, S.U., Khan, S.M., Khan, S.A. and Zamin, M. 2017. Integrated weed management in maize under different tillage regimes. Int. J. Biosci. 10(6): 223-231.

Rashid, H.U., Muhammad, D., Khan, M.A., Arif, M., Tahir, N., Zamin, M., Afridi, R.A., Azeem, M.T. and Azam, F. 2020. Impact of integrated 
weed management in maize on weed density, biological yield, and soil physicochemical properties. Int. J. Biosci. 16(5): 232-244.

Reddy, V. and F. Jabeen. 2016. Narrow sense heritability, correlation and path analysis in maize (Zea mays L.) SABRAO J. Breed Genet., 48(2): 120-126.

Safdar, M.E., Tanveer, A., Khaliq, A. and Naeem, M.S. 2014. Allelopathic action of parthenium and its rhizospheric soil on maize as influenced by growing conditions. Planta Daninha. 32(2): 243-253. https://doi.org/10.1590/S010083582014000200001

Spring, O., U. Rondon and F.A. Macías. 1992. Sesquiterpene from noncapitate glandular trichomes of Helianthus annuus. Phytochemistry, 31: 1541-1544.

Steel, R.G.D., Torrie, J.H. and Dicky, D.A. 1997.
Principles and Procedures of Statistics, A biometrical approach. 3rd Edition, McGraw Hill, Inc. Book Co., New York, 352-358.

Tangadulratana, R. 1985. Effect of tillage system, weed control and fertilizer application methods on growth and yield of maize (Zea mays L.). Kasetsart University, Bangkok. Graduate School, MLKU/TH (Thailand).

Vila-Aiub, M.M., Neve, P. and Powles, S.B. 2005. Resistance cost of a cytochrome P450 herbicide metabolism mechanism but not an ACCase target site mutation in a multiple resistant Lolium rigidum population. New Phytologist. 167(3):787-796. https://doi. org/10.1111/j.1469-8137.2005.01465.x

Weston, L.A. and Duke, S.O. 2003. Weed and crop allelopathy. Critical Reviews in P1. Sci., 22(3-4): 367-389. https://doi.org/10.1080/713610861 